\title{
THE EFFECTIVENESS OF AROMATHERAPY IN REDUCING PAIN DURING STAGE-1 OF BIRTH DELIVERY: A META-ANALYSIS
}

\author{
Uswatun Hasanah'), Bhisma Murti²), Hanung Prasetya3) \\ 1)Masters Program in Public Health, Universitas Sebelas Maret \\ 2)Faculty of Medicine, Universitas Sebelas Maret \\ 3)Health Polytechnics, Ministry of Health Surakarta
}

\begin{abstract}
Background: Aromatherapy is most commonly applied topically, or through inhalation (using a humidifier or by soaking gauze and placing it near the patient). Although many claims have been made relating to the benefits of aromatherapy, most study has focused on its use to manage depression, anxiety, muscle tension, sleep disturbance, nausea, and pain. This study aimed to explore the effectiveness of aromatherapy in reducing pain during stage- 1 of birth delivery.

Subjects and Method: A systematic review and meta analysis study was conducted by collecting articles from ProQuest, Science Direct, Schoolar Google, and Springer Link databases. The study population was intrapartum stage-1 women. The intervention was aromatherapy. It was compared with non-aromatherapy group. The study outcome was pain during stage-1 birth delivery. The inclusion criteria were full text, randomized controlled trial, and used English language. Selected articles were assessed using random effect model run on RevMan 5.3.

Results: 9 randomized controlled trials were processed to meta analysis. This study found that aromatherapy reduced pain in women during stage- 1 of birth delivery (SMD $-0.85 ; 95 \% \mathrm{CI}=-1.40$ to $-0.31 ; \mathrm{p}<0.001)$.

Conclusion: Aromatherapy is effective to reduce pain in women during stage-1 of birth delivery.
\end{abstract}

Keywords: aromatherapy, birth delivery pain, meta-analysis

\section{Correspondence:}

Uswatun Hasanah. Masters Program in Public Health, Universitas Sebelas Maret. Jl. Ir. Sutami 36A, Surakarta 57126, Central Java. Email: uusuusuuso@gmail.com. Mobile: 085647582541. 